ppi $201502 Z U 4645$

Esta publicación científica en formato digital es continuidad de la revista impresa ISSN-Versión Impresa 0798-1406 / ISSN-Versión on line 2542-3185Depósito legal pp $197402 Z$ U34
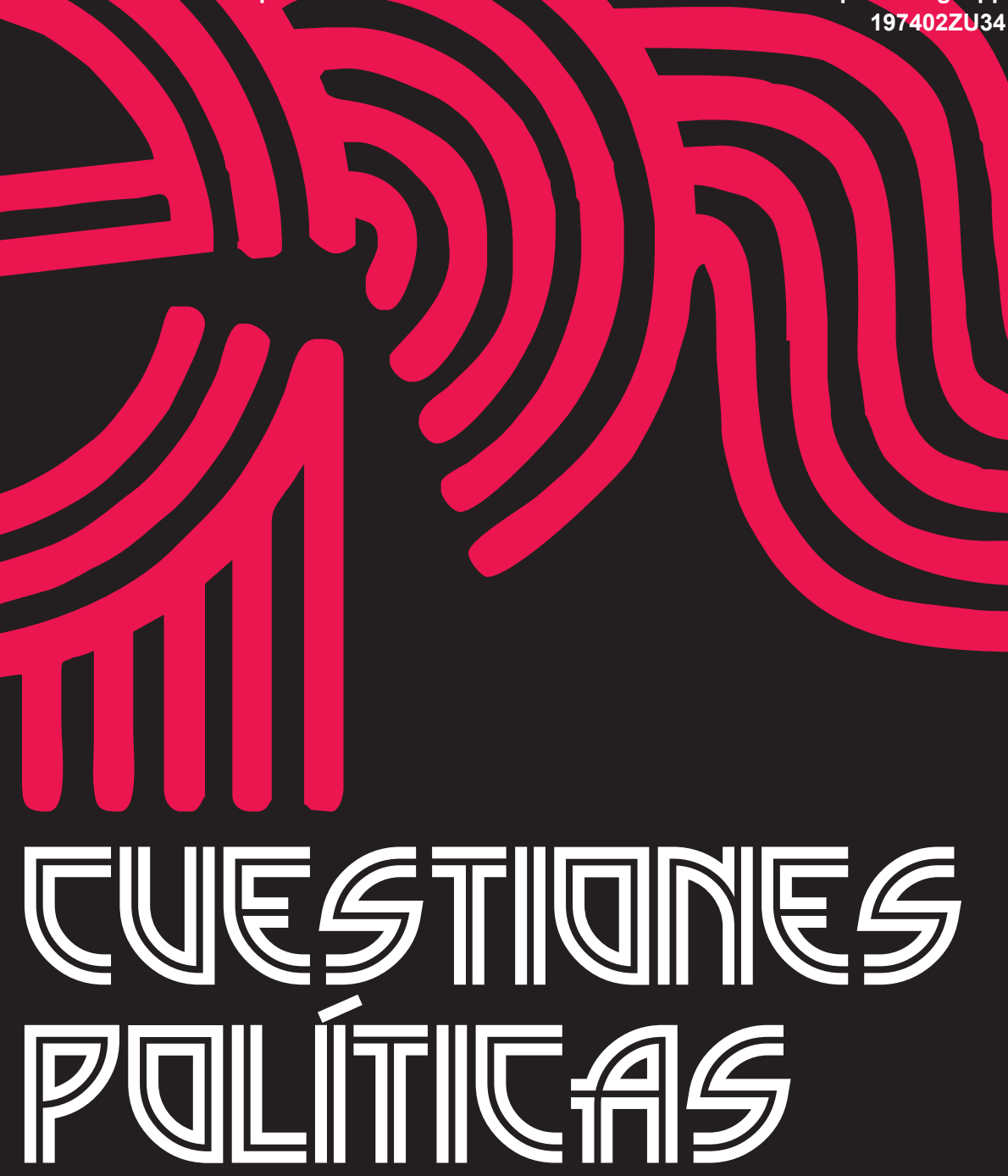

Instituto de Estudios Políticos y Derecho Público "Dr. Humberto J. La Roche" de la Facultad de Ciencias Jurídicas y Políticas de la Universidad del Zulia Maracaibo, Venezuela
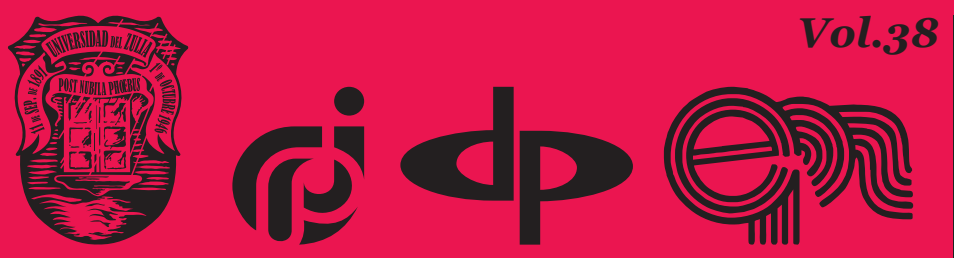

$N^{\circ}$ Especial 2da Parte 2020 


\title{
Foreign policy factor in State-Church relations in the Soviet Union during World War II and early post-war
}

\author{
DOI: https://doi.org/10.46398/cuestpol.382e.12
}

\author{
Ruslan Rustamovich Ibragimov * \\ Aivaz Minnegosmanovich Fazliev ** \\ Chulpan Khamitovna Samatova *** \\ Boturzhon Khamidovich Alimov ****
}

\begin{abstract}
The objective of the research was to study Russian State and Orthodox church relations in the context of world war II and the early post-war years. The line of this article is due to the important role of the Russian Orthodox Church in the history, modern political and cultural life of Russia. In this sense, the period of State-Church relations in the USSR during world war II, known in Russia as a great patriotic war, is of great scientific interest because it was the time when the government was forced to make adjustments to its religion policy. Methodologically based on a wide range of documentary sources, the authors of the article have identified the place and role of the Russian Orthodox Church in the foreign policy of the USSR during the approach. In this sense, it is felt that the role of the Russian Orthodox Church in building relations with the allies of the anti-Hitler coalition and its place in the expansion of the Soviet political system in Eastern Europe was of paramount importance as a foreign policy factor.
\end{abstract}

Keywords: Soviet state; Russian Orthodox Church; World War II; believers and clergy; Eastern Europe in the post-war period.

* Candidate of Historical Sciences, Associate Professor, Department of Russian History, Institute of International Relations. ORCID ID https://orcid.org/oooo-ooo1-8879-119o. Email: rus-ibr@inbox.ru

** Candidate of Historical Sciences, Associate Professor, Department of Russian History, Institute of International Relations. ORCID ID ID https://orcid.org/oooo-0oo3-4317-9533. Email: aivazik@ mail.ru

*** Candidate of Historical Sciences, Associate Professor, Department of Historical and Social Studies, Institute of International Relations. ORCID ID https://orcid.org/oooo-0001-5462-436X. Email: chulpan-samatova@mail.ru

**** Candidate of Historical Sciences, Associate Professor, Head of the Department of International Relations, Tajik State University of Law, Business and Politics (Republic of Tajikistan, Khujand). ORCID ID https://orcid.org/oooo-0oo3-4951-3379. Email: BAlimov@inbox.ru 


\section{Factor de política exterior en las relaciones Estado- Iglesia en la Unión Soviética durante la segunda guerra mundial y en los primeros años de posguerra}

\section{Resumen}

El objetivo de la investigación consistió en el estudio de las relaciones Estado e iglesia ortodoxa rusa en el contexto de la segunda guerra mundial y los primeros años de postguerra. La relevancia de este artículo se debe al importante papel de la Iglesia Ortodoxa Rusa en la historia, la vida política y cultural moderna de Rusia. En este sentido, el período de las relaciones Estado-Iglesia en la URSS durante la segunda guerra mundial, conocida en rusia como gran guerra patriótica, es de gran interés científico porque fue el momento en que el gobierno soviético se vio obligado a realizar ciertos ajustes en su política en materia de religión. En lo metodológico sobre la base de una amplia gama de fuentes documentales, los autores del artículo han identificado el lugar y el papel de la Iglesia Ortodoxa Rusa en la política exterior de la URSS durante en el periodo abordado. En este sentido, se concluye que el rol desempeñado por la Iglesia Ortodoxa Rusa en la construcción de relaciones con los aliados de la coalición anti-Hitler y su lugar en la expansión del sistema político soviético en Europa del Este fue de suma importancia como factor de política exterior.

Palabras clave: Estado soviético; Iglesia ortodoxa rusa; Segunda Guerra Mundial; creyentes y clero; Europa del Este en la postguerra.

\section{Introduction}

The scientific problem presented in the paper has long been in the focus of attention of domestic and foreign researchers. In the Soviet period, the history of state-confessional relations could be interpreted only from the perspective of criticism of religion. A similar approach to the coverage of this problem was demonstrated by Soviet historians; however, this does not reduce the scientific merit of their works (Akhmerov, 1962; Akhunzyanov, 1977; Baltanov, 1974; Gordienko and Kurochkin, 1980; Kalaganov, 1981). For example, they provide a wealth of factual material; a rigorous analysis concerning the aspects of how atheist propaganda was built is given.

The perestroika years and the post-Soviet period were characterized by the liberation of Russian humanitarian science from the ideological dogmas of the Soviet era, the emergence of historians' access to previously closed archival documents, and the use of new approaches in interpreting past 
Ruslan Rustamovich Ibragimov, Aivaz Minnegosmanovich Fazliev, Chulpan Khamitovna Samatova, Boturzhon Khamidovich Alimov

events. All these aspects were characteristic for the analysis of the history and the scientific problem under consideration (Braslavsky, 1995; Odintsov, 1994; Odintsov, 1995; Pospelovsky, 1995; Pospelovsky, 2000; Shkarovsky, 2000; Yakunin, 2002; Mukhin et al., 2018; Fazliev, 2016).

Foreign historiography has developed its own specific traditions and approaches to the study of state-church relations in the Soviet state. They were largely due to the uniqueness of political, ideological and sociocultural conditions, which, of course, was reflected in the interpretation of historical sources, the assessment of events and processes (Ramet, 1993; Anderson, 1994; Pipes, 1994; Peris, 1998; Husband, 2000). Despite the considerable attention of researchers to the history of state-church relations during the Great Patriotic War, some of its aspects are still poorly understood at present. These, of course, include the foreign policy circumstances of statechurch relations in this period.

By the beginning of World War II, the religious associations of the USSR were on the verge of complete destruction as a result of the massive ideological work of atheist propaganda, repressions against believers and the clergy, as well as after three all-Union anti-religious campaigns.

The situation radically changed in 1941 with the outbreak of World War II. Representatives of all faiths operating on the territory of the USSR made patriotic appeals to their followers. On the very first day of the war, a call for consolidation against the external enemy was made by Metropolitan Sergius, who actually headed the Russian Orthodox Church for 17 years. In his pastoral epistle, which was sent to all parishes, there were the following words: "Our Orthodox Church has always shared the fate of the people. ... Our ancestors did not lose heart also in worse situations, because they remembered not about personal dangers and benefits, but about their sacred duty to the Motherland..." (National Archives of the Republic of Tatarstan, 2015: p. 18). From June 1941 to August 1944, 30 appeals of the Metropolitan (from September 1943 - the Patriarch of Moscow and All Russia) Sergius to the clergy and believers with a call for unity in the struggle for the homeland were published (Yunusova, 1999).

The patriotic activity of believers and the clergy was expressed in a variety of forms ranging from direct participation in hostilities at the front and ending with the raising of material resources in the rear for the Red Army fund. For example, in one of his appeals on October 14, 1941, Metropolitan Sergius urged believers to "donate to our valiant defenders", and in December 1942, on his own initiative, fundraising began to form a tank column named after Dmitry Donskoy. For example, by March 1944, in the Tatar Autonomous Soviet Socialist Republic 1272.4 thousand roubles had been collected by religious associations of the cities of Kazan and Menzelinsk in the country's defence fund; in addition, about 4 pounds of gold were donated to the state and gifts were collected for soldiers and 
commanders of the Red Army, 476 items in total (National Archives of the Republic of Tatarstan, 2015).

The fact that religious organizations took a patriotic position and expressed their readiness to fully support and assist the Soviet government in its struggle against an external aggressor was a logical continuation of the religious organizations' policy of "peaceful coexistence" with a state power being hostile towards them. According to A.B. Yunusova: “....as it was before the war, both the church and believers often actively supported all kinds of initiatives and campaigns of Soviets... and did not oppose themselves to the country and authorities" (Yunusova, 1999: p. 35) A new phenomenon in relations between the state and the church was the response of the state authorities expressed in a significant liberalization of religious policy.

The reason for these steps was the situation not only within the country, the demand in the consolidating and compensatory functions of religion in the conditions of war, but also the international situation of that period.

\section{Methods}

The methodological basis of the paper was the civilizational approach, which allowed us to consider the object of study in a multi-aspect format influenced by political, ideological and sociocultural factors.

In the course of work with the paper, the authors adhered to the principles of historicism and objectivity. The first of them obliged to consider and analyse events taking into account the political-ideological and moralethical foundations of the era under study. The second factor obliged to dissociate ourselves from various extra-scientific factors: personal likes and dislikes in assessing the historical facts and processes under consideration.

\section{Results and Discussion}

The Soviet Union, which was at war alone with fascist Germany, faced an important task: the opening of a second front by its allies. Under these conditions, the democratization of certain aspects of the Soviet society life could favourably affect the course of negotiations with the Allies. The fact is that the leaders of the Allied countries were subjected to considerable pressure from various public organizations of these states in order to open the second front by them as soon as possible. In Great Britain, this was the Joint Committee for Assistance to the USSR headed by the rector of Canterbury Cathedral, H. Johnson. In turn, the Church of England, of 
Ruslan Rustamovich Ibragimov, Aivaz Minnegosmanovich Fazliev, Chulpan Khamitovna Samatova, Boturzhon Khamidovich Alimov

which the aforementioned person was a representative, persistently sought Stalin's permission to visit the Soviet Union.

In order to make the "necessary" impression on the delegation, the Soviet government needed to review some of the toughest and most odious moments in its religious policy. In addition, according to D.V. Pospelovsky, "Churchill and Roosevelt made it clear to him (Stalin) that information on religious freedom in the USSR could adjust the public opinion of their countries in favour of the Soviet Union" (Pospelovsky, 2000: p. 53). Therefore, it was no coincidence that the Soviet state authorities officially recognized the merits of religious organizations and believers on the eve of the high-level talks in Tehran.

Indeed, after Stalin's meeting on September 4, 1943 with the leaders of the Russian Orthodox Church, during which decisions were made that marked a new stage in state-confessional relations, then two weeks later, a delegation of the Anglican Church of England headed by the Archbishop of York S. Garbett visited the USSR.

Chairman of the Council for Russian Orthodox Church, NKVD (People's Commissariat for Internal Affairs) Colonel G.G. Karpov compiled a detailed report in the name of Stalin on this visit (Power and the church in Eastern Europe, 2009). During it, the delegation twice (September 21 and 23) visited the Epiphany Cathedral church.

At the same time, Archbishop Garbet was impressed by the large number of believers present. Later, he noted, "I have never seen such a large gathering of worshipers. Throughout the service of September 21, a crowd of people stood on their feet. They said that there were about ten thousand of them ..." (Garbett, 1943: p. 8). However, Karpov in his memo to Stalin indicated a more modest figure: about 4 thousand people on September 21 and about 6 thousand on September 23 (Power and the church in Eastern Europe, 2009). The Archbishop of York was interested in the following questions, among others, during meetings with the heads of the Russian Orthodox Church (Power and the church in Eastern Europe, 2009):

- The number of churches in dioceses and, in particular, in Moscow;

- How are clergy staff trained?

- Why are there monasteries in Ukraine, but not in other places?

- Why in cemeteries are there stars on some graves, and crosses on others?

- Will the temples destroyed by the Germans be restored?

- If a believing soldier is killed, is it possible to install a cross as his grave? 
Despite the fact that many of the questions asked should put the Soviet clergy in an uncomfortable position caused, on the one hand, by the realization of the real situation of the church in the USSR, and on the other hand, by the need to "play along" with the state authorities in exchange for their relative loyalty, the atmosphere of the meetings was generally very welcoming and benevolent on both sides. It was decided to establish an exchange of information about church life between the Russian Orthodox and Anglican churches, and during the last meeting with the patriarch, the Archbishop of York said: "Upon arrival in England, I will be besieged by correspondents; they will ask if there is freedom of worship in Russia", and I will answer that "definitely yes" ... (Power and the church in Eastern Europe, 2009: p. 15). Thus, on the part of the Soviet state, the goals of the visit were fulfilled: representatives of the Church of England were convinced of the loyalty of the Soviet regime to believers and the clergy.

Another important aspect of the foreign policy factor in state-church relations in the USSR was the position of religion in the countries of Eastern Europe. It is no coincidence that at a meeting between Stalin and NKVD Colonel G.G. Karpov on September 4, 1943 (the previous meeting of the head of the Soviet state with the hierarchs of the Russian Orthodox Church), among others, the colonel of state security was asked the following questions: what kind of relations does the Russian Orthodox Church have with foreign countries and what does Karpov know about the leadership of the Orthodox churches in Bulgaria, Yugoslavia, and Romania? (Power and the church in Eastern Europe, 2009)

Such interest in that period was determined by two main reasons. First, the authorities recognized the consolidating role of the church in the antifascist movement in the occupied territories. In this regard, the authorities strongly supported the practice of appeals by hierarchs of the Russian Orthodox Church to their foreign followers. For example, in the spring of 1943, after the approval by the Central Committee of the All-Union Communist Party of Bolsheviks of the appeal by Metropolitan Sergius "To all Christians in Yugoslavia, Czechoslovakia, Hellas and other countries and peoples groaning beneath the Nazi occupiers" was printed and sent across the front line (Mukhin et al., 2018). Metropolitan Nikolai repeatedly wrote anti-fascist messages to the peoples of Eastern Europe also (Pospelovsky, 2000).

Secondly, after a radical change in the Great Patriotic War, it became clear that the countries of this region would soon enter the sphere of influence of the Soviet Union. The specificity of their socio-economic condition was that all of them, with the exception of Czechoslovakia, remained agrarian or agrarian-industrial countries, where, along with the weak sprouts of capitalism, feudal orders dominated. The last expressed, among other things, in the significant influence of the Catholic Church. In addition, one 
Ruslan Rustamovich Ibragimov, Aivaz Minnegosmanovich Fazliev, Chulpan Khamitovna Samatova, Boturzhon Khamidovich Alimov

Foreign policy factor in State-Church relations in the Soviet Union during World War II and early post-war

should take into account the confessional peculiarity of the western regions of the USSR, which became part of it after the Soviet-German agreements of 1939. The Greek Catholic (Uniate) church was the spiritual basis of the nationalist movement in Western Ukraine and its positions were strong here.

The Russian Orthodox Church, as well as other religious organizations operating in the Soviet state, was forced to declare their loyalty to state power, and the Vatican declared its rejection of the "godless Bolshevik regime" immediately after the October Revolution. That's what in May 1945 the chairman of the Council for Religious Cults under the Council of People's Commissars of the USSR I.V. Polyansky wrote about this in a directive letter to his local representatives: "The papal throne systematically organized attacks from the Vatican Palace in various forms against the USSR... The Vatican uses all possible means to maintain its authority and take an active part in the development of the post-war organization of the world and its security" (Power and the church in Eastern Europe, 2009).

In this situation, the assistance of the Russian Orthodox Church was very helpful. In exchange for the normalization of state-church relations within the country, it was to convince its followers in those regions of the Soviet regime's loyalty to religion, and in the future it become one of the channels to educate their population according to Soviet moral and ethical values.

The Soviet leadership considered the most effective way in the fight against the influence of the Catholic and Uniate churches was to strengthen the position of the Russian Orthodox Church in the regions where the above religions are spread. First of all, this was supposed to be done by providing it with certain opportunities in missionary activity. In this regard, Chairman of the Council for Russian Orthodox Church Affairs under the Council of People's Commissars of the USSR G.G. Karpov in his memorandum for I.V. Stalin dated March 15, 1945 proposed to organize an Orthodox diocese in the city of Lvov.

He also proposed to provide the clergy of the diocese with the right to carry out missionary work; to transfer one of the Uniate's churches to the disposal of the Orthodox diocese in Lvov as a cathedral (Power and the church in Eastern Europe, 2009). Also, the Soviet government initiated the work of the Moscow Patriarchate on entering into its jurisdiction of Orthodox parishes located abroad. In many cases, the diplomatic activity of the church had a positive response among them. This was explained, first of all, by their hopes to receive financial and political support from the Moscow Patriarchate in confrontation with other faiths, primarily with the Roman Catholic and Uniate ones. The results of cooperation between the authorities and the church in this matter turned out to be very significant. So, according to historian M. Shkarovsky: "Only in 1945 trips of its (i.e., 
Russian Orthodox Church) delegations to 15 countries were organized. As a result, three new metropolitans, 17 bishops and 285 parishes entered into the jurisdiction of the Russian Church" (Shkarovsky, 2000: p. 29; Mukhin et al., 2018).

Against the background of such results, Soviet diplomacy seriously considered the church as a tool for spreading its influence in the post-war world. In this regard, in 1948 it was planned to convene the Ecumenical Council with the aim of conferring the Moscow Patriarchate the Ecumenical title, ensuring its leadership status not only in the Orthodox, but in the whole Christian world. However, these global plans were not destined to come true. Firstly, in 1948, the anti-Soviet archbishop of New York Athenagoras was elected the Patriarch of Constantinople; he called for the cooperation of Christians and Muslims to fight communism. Secondly, even the Vatican's very ambiguous position towards the Nazi regime during the Second World War was not able to seriously shake its position. The Roman Catholic Church continued to play a significant role not only in the spiritual, but also in political life. So, in the spring of 1947 the Communists lost their places in the governments of Italy and France, apparently, not without participation of the Roman Catholic Church.

In 1948, the foreign policy activity of the Moscow Patriarchate fell sharply, because part of the problems for the solution of which the state's policy towards the church was relaxed, was resolved. So, in 1946 there was a reunion of the Uniates of the western regions of the USSR with the Russian Orthodox Church; besides, pro-Soviet regimes in Eastern Europe strengthened their power. The task of turning Moscow into the centre of the Christian world due to the previously mentioned reasons turned out to be impossible.

\section{Conclusions}

Thus, despite the generally anti-religious nature of the Soviet political and ideological system, the Russian Orthodox Church became an important tool of the foreign policy of the USSR during the years of World War II.

In the late 1940 , the period of relative normalization of state-church relations was curtailed. In this regard, the foreign policy of the Russian Orthodox Church was mainly limited to participation in the movement on the struggle for peace until the end of the 1980s. Partly, due to the loss of interest of the state authorities in the foreign policy of the church, the policy of the Soviet state regarding religious associations within the country was tightened again, which resulted in the termination of registration of actual religious associations, administrative pressure and increased atheistic propaganda. 
Ruslan Rustamovich Ibragimov, Aivaz Minnegosmanovich Fazliev, Chulpan Khamitovna Samatova, Boturzhon Khamidovich Alimov

\section{Acknowledgements}

The work is performed according to the Russian Government Program of Competitive Growth of Kazan Federal University.

\section{Bibliographic References}

AKHMEROV, Zerina. 1962. To educate atheists. From the experience of the schools of the TASSR. Academy of Pedagogical Sciences of the RSFSR. Moscow, Russia.

AKHUNZYANOV, Tatuya. 1977. “The subject of special attention” In: Science and religion. Vol. 4, pp. 35-38.

ANDERSON, John. 1994. Religion, State and Politics in the Soviet Union and Successor States. Cambridge University Press. Cambridge, UK.

BALTANOV, Ravil Gubaidullovich. 1974. The main problems of a concrete sociological analysis of religion and atheism in the USSR: Thesis for the degree of Doctor of Philosophy. Kazan State University. Kazan, Russia.

BRASLAVSKY, Lido Yu. 1995. Orthodox churches of Chuvashia. Chuvash Book Publishing House. Cheboksary, Russia.

FAZLIEV, Aivaz. 2016. "Church-state relations in conditions of social and political transformation of Russia (by the example of Tatarstan)" In: Man in India. Vol. 96, No. 3, pp. 763-770.

GARBETT, Sandra. 1943. What I saw in the USSR. "British Ally", October 31. P.8. Moscow, Russia.

GORDIENKO, Nevada; KUROCHKIN, Pavel Konstantinovich. 1980. "The main features of the evolution of religion and the church in a socialist society" In: Questions of scientific atheism. Vol. 25, pp. 223-243

HUSBAND, William B. 2000. "Godless Communists": Atheism and Society in Soviet Russia, 1917-1932" DeKalb: Northern Illinois University Press. Illinois, United States.

KALAGANOV, Andre. 1981. "On the attitude of the CPSU and the Soviet state towards religion and the church" In: Agitator's Notebook. Vol. 8, pp. 1619. 
MUKHIN, Vladimir; DAVYDOV, Denis; FEDOROVA, Natalia. 2018. "Repressions, Economic Pressure and Survival Strategies of the Orthodox Clergy in Kazan Diocese in the 1930s" In: Gosudarstvo Religiya Tserkov v Rossii i za Rubezhom, Vol. 36, No. 3, pp. 102-120 (Q1).

NATIONAL ARCHIVES OF THE REPUBLIC OF TATARSTAN. 2015. Fund R-873. Inventory 1. Case 2. Sheet 18.

ODINTSOV, Mikhail. 1994. State and church in Russia: XX century. M.: Luch. Cheboksary, Russia.

ODINTSOV, Mikhail. 1995. "Religious organizations in the USSR: on the eve of and in the first years of World War II (1938-1943)" In: Domestic archives. Vol. 2, pp. 65-67.

PERIS, Daniel. 1998. Storming the Heavens: The Soviet League of the Militant Godless. Cornell University Press. New York, United States.

PIPES, Richard. 1994. Russia Under the Bolshevik Regime. Alfred A. Knopf. Samara, Russia.

POSPELOVSKY, David. 1995. Russian Orthodox Church in the XX century. M.: Republic. Moscow, Russia.

POSPELOVSKY, David. 2000. How Stalin revived the church. Nezavisimaya Gazeta. Moscow, Russia.

POWER AND THE CHURCH IN EASTERN EUROPE. 2009. 1944-1953 Documents of the Russian archives: in 2 volumes. Vol.1. - M.: Russian Political Encyclopedia (ROSSPEN), 22-27.

RAMET, Sabrina. 1993. Religious Policy in the Soviet Union. Cambridge University Press. Cambridge, UK.

SHKAROVSKY, Mikhail. 2000. Russian Orthodox Church under Stalin and Khrushchev. (State-church relations in the USSR in 1939-1964). Moscow, Russia.

YAKUNIN, Venda. 2002. Russian Orthodox Church during the Great Patriotic War of 1941-1945: historiography and source study of the problem. Salv. Samara, Russia.

YUNUSOVA, Aislu B. 1999. Islam in Bashkortostan. Ufa. Moscow, Russia. 
Vol.38 NEspecial

Esta revista fue editada en formato digital y publicada en diciembre de 2020, por el Fondo Editorial Serbiluz, Universidad del Zulia. Maracaibo-Venezuela 